\title{
Science and Society
}

\section{The Historical Consciousness of Modern Russian Society}

\author{
A. L. Andreev ${ }^{\#}$ \\ Federal Research Sociological Center, Russian Academy of Sciences, Moscow, Russia \\ e-mail: sympathy_06@mail.ru \\ Received January 11, 2021; revised January 18, 2021; accepted February 5, 2021
}

\begin{abstract}
What is the current assessment of the comparative significance of historical events in the mass consciousness of Russians? From what sources do our compatriots draw their knowledge about the past of the country? Can one talk about "good" and "bad" eras in the development of Russia? Based on the materials of empirical research, the author of this article undertakes an attempt to analyze the dynamics of features characteristic of the historical consciousness of Russian society. In his opinion, the transformation of people's ideas about the historical path of the country can be considered as one of the analytical tools for early diagnostics of the changes simmering in society. In addition, a conclusion is formulated that Russian society demonstrates an expressed demand for the elaboration of stable historical reference points and interpretations, a certain unified historical narrative.
\end{abstract}

Keywords: historical consciousness, historical competences, images of history, historical truth, interpretations of history.

DOI: $10.1134 / \mathrm{S} 1019331621020118$

The images of history are polysemantic, and one can often see prototypes of modernity in them-to the extent to which historical memory influences the emotional-conceptual structures of identity and through them affects the mass consciousness and political behavior. At the same time, historical ideas form a specific cognitive structure, which can be defined as the initial matrix of understanding that allows for the primary emotionally tinted identification of phenomena, processes, and symbolic leaders arising in the social field. Accordingly, when in any society, for some reason (for example, social or geopolitical), the need to search for one's identity arises again, the request for certain images of history, sometimes completely new ones, also occurs.

There are many examples of this: fascination with antiquity in the Renaissance, imitation of the Roman republicans during the French Revolution, the interest of Romanticists in the Middle Ages, the Jacobinism of the Russian Bolsheviks, Confucian reminiscences in modern China and Ottoman reminiscences in modern Turkey, historiographic experiments and historical mythmaking of the "new democracies" of Eastern Europe, and the actively promoted revision of US history from the standpoint of "racial righteousness" and political correctness. One may suggest that mutations in the conceptual structure are early symptoms of new

\footnotetext{
\# Andrei Leonidovich Andreev, Dr. Sci. (Philos.), is Chief Researcher at the RAS Federal Research Sociological Center and a Professor at National Research University "Moscow Power Engineering Institute.”
}

social demands and trends. If so, monitoring the perception of history can serve as one of the tools of social diagnostics and political forecasting.

As is known, the Russian historical narrative has changed many times, reflecting the zigzags of the path that we have traveled. Accordingly, ideas about historical truth also changed. Where has this ambiguous and contradictory path brought us to in the long run, and how does Russian society today imagine its past and its connection with the present? To answer this question, we will use the materials of the Russian sociological survey conducted by the Federal Research Sociological Center of the Russian Academy of Sciences in the fall of $2020,{ }^{1}$ as well as the data of some other studies.

\section{WHAT IS THE ORIGIN OF MASS HISTORICAL VIEWS?}

Note that quite a few people in our country are interested in history (much more in Russian than in foreign history), and Russians understand the significance of historical views in the life of society quite well. Judging by the data obtained in our research, from a quarter to a third of the country's population believes that the historical past is one of the main factors uniting the nation and the state. In Russia, as well

\footnotetext{
${ }^{1}$ The survey was conducted in September 2020 in all territorial and economic regions of the Russian Federation (according to Rosstat's zoning). The sample is representative, and the sample size is 2000 people. Below, the results of this survey are given without reference, only the results of other surveys are specified.
} 
as in other countries, the need to know and understand the past is more often characteristic of middleaged and older people than of the young. However, to an even greater extent, this need is determined by the level of education. Thus, among our respondents who have only a school diploma, $43 \%$ are interested (on a constant basis or from time to time) in world history, and $57 \%$ in domestic history, while among those who graduated from universities, 68 and $80 \%$ are, respectively. These indicators are noticeably influenced by the degree of activity on the Internet as well: the respondents who use it daily have higher indicators than those who rarely or never access the World Wide Web.

Even though in secondary and higher educational establishments absolutely all citizens of Russia study history for a fairly long time, seven to eight years, our respondents claim that the contribution of school and college education to the formation of their views on history is rather moderate: only a little more than $20 \%$ of the respondents considered it the most important source of information. However, among young people under 30, this indicator turned out to be about 1.5 times higher than the average for the sample: apparently, fresh memories of their studies do have an effect, and they have not yet had time to get to know other sources. Most often, however, representatives of almost all sociodemographic groups receive a variety of historical information through cinema and television. Almost $45 \%$ of our respondents named historical feature films and series as the main source of knowledge about history, and $40 \%$, historical documentaries. Only young people under 30 mention the Internet on a par with historical feature films (but ahead of documentaries). Various specialized programs and television talk shows should be added to the list of screen genres, although only $13 \%$ mentioned them.

It seems that Russians' preferences in historical films that stick out in their memory show to an extent the emotional tonality of the perception of past events. The respective question was asked in an open form (that is, the survey participants had to answer it themselves and not choose from proposed alternatives), and the respondents named about 320 films and TV series in total. Thus, people do watch historical films, only one in five respondents was not interested in them. However, the preferences of $80 \%$ of those interested are rather vague.

In general, the absolute predominance of domestic films in the compiled list is noteworthy. Foreign films (even if we include those made jointly with Russian filmmakers) accounted for $11 \%$ of this list at best. Costumed blockbusters such as Rome, Gladiator, Troy, or The Golden Age prevail among the foreign films noted by our respondents, although among them there are also films about WWII with a strong moral connotation. Domestic films are present in the widest rangefrom the unfading classics of prewar Soviet cinema
(Battleship Potemkin, Alexander Nevsky, etc.) to works shot in the most recent years (Battle for Sevastopol, Admiral, Panfilov's 28 Men, and others). The champion of audience choice was the film War and Peace by Sergei Bondarchuk, a classic of world cinema, which brought together the significance of the era depicted; loyalty to historical truth, reaching scrupulous accuracy in everyday details; the philosophical depth of the great novel by L.N. Tolstoy; and Bondarchuk's outstanding direction. Following this film, rating positions with practically the same result were taken by the historical drama Peter the Great: The Testament and the already classic war film The Dawns Here Are Quiet.

Quite rich information for considering the perception of history and the properties of historical memory is provided by an analysis of the thematic distribution of the films noted by our respondents. The largest share among them (about a fifth) are Soviet and Russian films about the Great Patriotic War, which once again confirms the system-forming role of this historical event in the collective consciousness of Russians. The historical revolutionary theme and the events of the Civil War and their echoes in the life of the country were reflected in $6-7 \%$ of the list compiled according to audience preferences. Note the almost complete oblivion of the cine-Leniniana, created in Soviet times. Although, as is shown by our survey, Russians continue to consider Lenin a great figure, out of all films dedicated to him, our respondents named only one, Lenin in October, but it had only a few fans $(0.1 \%$ of the total number of respondents).

Against this background, a growing interest in films dedicated to the Russian imperial dynasty is noteworthy. These are Peter the Great; the television series The Great, which tells about the youth of Catherine II; and the documentary television project The Romanovs (which, by the way, in terms of popularity follows immediately after the three leaders of Russian historical cinema identified in our survey). It would not be superfluous to compare this interest with the mass visits of residents of Russian cities to exhibitions, as well as other events held in 2013 to mark the 400th anniversary of the House of Romanov.

However, not the screen alone.... Note that the Russian public traditionally loves historical novels, although, according to our respondents, as a source of knowledge and ideas about the past, they are significantly inferior to screen works. Obviously, people over 40-50 years of age read more readily than young people. Among respondents aged $50+$, about $30 \%$ draw historical information from literary works, while in the age group under 30 , only $20 \%$. Of course, this is by no means a negligible figure. However, it is noticeable that among the young a novel, a novella, a short story as narrative forms of mental representation of history are being replaced by clip forms, in particular, a chaotic search for information on the Internet, which in this group surpassed the book in popularity by about 
1.5 times (whereas in the older age cohorts, this relation turned out to be exactly the opposite). Another way to feel the influences of bygone eras is by visiting exhibitions and museums, tourist trips, and excursions (this was mentioned by almost $25 \%$ of the respondents).

At the same time, currently fashionable computer games with historical plots serve as a guide to the world of history for only $3.5 \%$ of Russians, mainly the young: among young people under 30, about $9 \%$ draw their historical ideas from games. However, even in this group, computer games are in the last place as a source of historical images and information, 2-3 times inferior in importance to films, textbooks, fiction, museums, and narratives of relatives. It is important to note this result, bearing in mind that in recent years some experts have suggested a wider use of game methods of studying history, including the use of computer games. This approach, in particular, is considered promising by American methodologists working under the programs of the Woodrow Wilson Foundation [1]. It would probably be useful to conduct further research in this direction, but the data of our survey make us view this approach with some skepticism, at least in Russian conditions.

Note that, giving credit to the screen and the book, many Russians highly value various ways of touching the past personally - the memories of loved ones, family legends and archives, carefully preserved antiques. This source of historical information in the eyes of our respondents turned out to be almost as important as the screen images of history: it was mentioned in the answers of about a third of our respondents. Undoubtedly, it was precisely on the basis of the emotional conjugation of the country's history with the stories of concrete families that such socially significant symbolic actions of recent times as "The Immortal Regiment" and "The Last Address" emerged.

Of course, it is not surprising that people turn to history reflected in living and visual images, captured in various kinds of artifacts, much more willingly than to dry scientific texts or even popular science publications. Nevertheless, it should be noted that in Russian society there is a certain core of serious history lovers, vividly distinguished in the general mass, for whom the main source of knowledge is scientific literature, up to strictly special studies. Based on the self-assessments and self-reports of the respondents, we can state that this core constitutes at least $12 \%$ of Russians, and, possibly, exceeds $15 \%$. The presence of people of this type in Russian society, in my opinion, has become one of the important factors that have blocked the widespread dissemination of various falsifications of Russian history in our country, as well as the reformatting of the historical consciousness of Russians in the style of folk history, "new chronology," etc.

\section{THE PROBLEM OF HISTORICAL COMPETENCE}

The following question arises: how efficiently does the complex of various sources of information work and to what extent is their use functional from the standpoint of receiving sufficient knowledge in terms of social needs and demands and adequate understanding of sociohistorical processes? We have been facing serious problems here of late. Experts in various countries note a decline in the historical competence of the mass strata of the population, and this largely contributes to the spread of such a specific feature of modern political culture as the so-called historical wars.

The American Council of Trustees and Alumni (ACTA) published an alarmist report on this topic in 2000 under the characteristic title "Losing America's Memory" [2]. The conclusions formulated in it were confirmed by subsequent sociological studies, carried out by various research structures, universities, and public associations. For example, a 2012 survey by the Woodrow Wilson Foundation showed that a significant proportion of Americans do not know with whom their country fought in World War II. In only four states out of the fifty did the share of those who answered this question correctly reach $60 \%$, while in many, including the most densely populated ones, it was $50 \%$ or less (in Louisiana, $43 \%$ ) [3]. This is noticeably worse than similar Russian indicators. For comparison, according to a survey conducted by the Russian Public Opinion Research Center (VTsIOM) in early September 2020, 77\% of Russians confidently answered that Germany was the main enemy of the Soviet Union in the Great Patriotic War [4].

The results of recent studies have shown a characteristic pattern: historical competences decline as generations change. This process is typical of almost all countries. In particular, older Americans are much more correct in answering concrete questions on US history than young people, including university and college graduates [5, p. 161]. The decline in historical competences in Russia, especially among young people, is also noticeable. Its manifestations, empirically recorded by sociological diagnostics, clearly correlate with the transition from the Soviet school to the postSoviet school, based on the principle of providing "educational services" [6]. American experts justifiably complain that in many US states nine out of every ten (and in Kentucky, ten out of eleven) citizens surveyed could not answer correctly when the document sacred for national historical memory, the US Constitution, was written [3]. Yet we also were not at all pleased with the fact that one in six Russians was not able to name the Russian emperor under whom serfdom was ended, Alexander II, which was revealed in a survey conducted in the fall of 2020, and every seventh had no idea who Yu.V. Andropov was. 
Unfortunately, we have no comparative data at our disposal that would allow us to compare the opinions of Russians about their historical knowledge over the years. However, at present, our compatriots clearly assess themselves in this sense moderately critically. Approximately one person out of every nine to ten considers him- or herself fully competent in this area, and this, note, is two times less than the share of respondents who, according to them, are interested in the events of the past. More than half believe that they have some general idea of Russian history. However, there are also quite a lot of those who consider themselves insufficiently knowledgeable in these issuesabout a third of the respondents.

\section{PERCEPTION OF ERAS AND EVENTS IN THE MASS CONSCIOUSNESS}

Nevertheless, when asked which events had the greatest impact on the history of Russia (it was possible to choose up to five answers out of 20 proposed), Russians answer quite confidently; in our survey, only one out of ten people found it difficult to express their opinion on this subject. Our respondents ranked the Great Patriotic War in first place among significant historical events (60\% of the votes), which was quite expected. Yet the fact that the Christianization of Rus' was in second place with a result of about $33 \%$ is not trivial, especially considering the rather indifferent attitude of most of our citizens to religion. Note also that the Baptizer of Rus'-Holy Prince Vladimir, Equal of the Apostles-was recognized as the second most important on the rather extensive list of figures who had a positive impact on the historical fate of Russia (next to Peter the Great).

The Great Patriotic War is followed in our rating by a number of events that were mentioned by $20-25 \%$ of respondents: the liberation of Russia from the Tatar-Mongol yoke, the abolition of serfdom, the establishment of the Russian Empire, the October Revolution of 1917, the creation and collapse of the Soviet Union, and Yu.A. Gagarin's space flight. These subjective assessments more or less correspond to the objective significance of historical phenomena. However, there were some surprises here as well. For example, Russians seem to underestimate the significance of the transition to a market economy: only $11 \%$ of the respondents mentioned it in their answers. Only 7-8\% noted landmarks such as the Gathering of the Lands by Moscow, the liberation of Moscow from the Polish invaders in 1612, and democratization and the elimination of the Iron Curtain between the Soviet Union and the West. Very few votes (less than 5\%) were for including in the list of the most important historical events the Peasants' War under the leadership of Emel'yan Pugachev; the Decembrist revolt; and, finally, the February Revolution, which many historians and political publicists regard as a pivotal chance for Russia to have entered the community of "nor- mal," "civilized" democracies. It is surprising that our respondents were rather dismissive of the reunification of Ukraine with Russia in 1654: less than $4 \%$ of the respondents recognized the high historical significance of this international act, although Crimea's secession from Ukraine and its reunification with Russia in 2014, on the contrary, were attributed to important events by $20 \%$.

During our research, for several years a diagnostic question was asked, which allows us to characterize not only the value orientation of the historical consciousness of Russians but indirectly also the connection between the historical consciousness and modernity, including the current social ideas and political views of the country's citizens. Namely, we asked them to choose which periods in the country's historical development most corresponded to their ideals and in which they would have liked to live. This question was periodically asked to our respondents over two decades, which allows us to make certain comparisons that characterize the dynamics of the historical consciousness of Russian society.

According to the data of a number of our surveys, Russians are by no means inclined to seek their ideals in the distant past. The overwhelming majority of our fellow citizens do not look beyond the horizon of what can be called actual history, reflected in their life world and the impressions they draw from there-both their own and direct eyewitnesses. In the early 2000s and later, the choice of most respondents was divided between two stages of this directly experienced history-the "golden fall" of Soviet power, preserved in the memory of millions of people (mainly under L.I. Brezhnev), and the current period, personified in the first place by the current President of the Russian Federation V.V. Putin. Accordingly, the respondents assessed these two statesmen approximately equally: the share of respondents who believed that these two persons played a positive role in the history of our country was $36 \%$ (Brezhnev) and $40 \%$ (Putin). In addition, about half of the respondents believe that there are both positive and negative aspects in the activities of these political leaders. Relatively few have an unequivocal negative attitude to Brezhnev and/or Putin-no more than $10-12 \%$. No other leader of the Soviet era enjoys such assessments. For example, only a little more than a quarter of the respondents approve of such figures of worldwide historical importance as Lenin and Stalin, and more than half of the respondents assess them negatively. Russians are even less enthusiastic about the merits of N.S. Khrushchev and Yu.V. Andropov and still less, about M.S. Gorbachev, B.N. Yeltsin, and E.T. Gaidar: the share of respondents who recognize at least some kind of merits for the leaders of perestroika and postperestroika reforms does not exceed 5-6\%, while the number of those who categorically disagree with them is $8-10$ times greater. 
It is no wonder that nostalgia for Brezhnev's "developed socialism" is mainly the lot of the older and, partly, middle generations, while young people, who did not see that era or saw it only in early childhood, emotionally identify themselves with the present, which, as it seems to many, not without reason, opens good prospects for them. However, all generations of Russians agree on one thing: they completely reject both perestroika and the interlude of "the holy 1990 s" with their characteristic dominance of oligarchy, rampant corruption, banditry, financial pyramids, the collapse of high-tech industries, and the sale of national wealth-everything that left almost no chance for decent self-realization to hardworking, well-educated, and law-abiding citizens. However, society for the most part excludes a rollback to the Stalinist "order," when even simple carelessness in the performance of official duties, not to mention some more serious misconduct, was punished with the most severe repressions.

Thus, the view of our fellow citizens on the logic of the historical development of Russia at the turn of the 20 th century is overall stable. However, there are some shifts in the proportions owing to both the natural change of generations (the number of citizens who lived in the Soviet era is decreasing) and some opportunistic factors. For example, the coronavirus pandemic, which seems to have nothing to do with the historical consciousness of society, can in fact influence it by stimulating pessimistic sentiments and, accordingly, adding negativity to the experience of the present moment.

Undoubtedly, the emotional connection of Russian society with the Brezhnev era is gradually withering. Of course, this is natural. However, this process is by no means a primitive monotonous decrease of the corresponding indicator; its configuration is more complex. In the early 2000 s, up to $35 \%$ of respondents chose that period as their preferred time, while in the 2014 survey the corresponding indicator only slightly exceeded 19\%; by now, however, its decline has either stopped or slowed down to the same level, $19 \%$. According to the results of our survey, the number of respondents whose ideals do not go beyond the today's or yesterday's present totaled over $40 \%$. This is about two times more than the sum of answers tending to idealize some other periods.

It is somewhat surprising that modern Russian society is practically not at all fascinated by the romanticism of the Sixties, despite the unfading popularity of the bardic lyrics of that time and the wonderful television series The Thaw, dedicated to that time (which, by the way, did not make it into the list of films from which Russians "learn history"). Even the Stalinist period, the criticism of which once promoted the rise of Khrushchev, appears more worthy of respect in the eyes of our fellow citizens, although conditional "Stalinists" among the respondents are few (according to the latest data, slightly more than $4 \%$ ). It can be assumed that, in the disorderly and contradictory Khrushchev, modern Russians see the forerunner of Gorbachev and Yeltsin, who broke down the Soviet Union. Perestroika, like the Yeltsin era, is still completely rejected by Russian society. To all appearances, the number of their adherents over the past few years has decreased even more, although we cannot state this for sure, since with the values of the corresponding indicators that we get in the course of surveys, small fluctuations in one direction or another fit within the statistical error.

Despite some efforts to popularize the imperial past, its idealization is still not typical of modern Russian society. At least, to date. At the same time, that era is rated by Russians more highly than any period of Soviet history prior to the "Brezhnev era." Our respondents voted for tsarist Russia 2.5 times more often than for Khrushchev's Thaw, almost five times more often than for perestroika, and 11 times more often than for market reforms of the early 1990s. Interestingly, the last Russian emperors, including Nicholas II, whose reign ended with the destruction of the state and was followed by many years of turmoil, are now perceived by Russians much more favorably than the leaders of perestroika and the architects of market reforms. In particular, the balance of polar assessments of Nicholas II according to the results of the survey conducted in the fall of 2020 amounted to $+12 \%(25 \%$ of the respondents considered that he had certain merits to Russia, and $13 \%$ recognized his role in history as undoubtedly negative), while for Gorbachev, Yeltsin, and Gaidar, the values of this indicator are significantly negative $(-51,-55$, and $-43 \%$, respectively).

Note that a kind of historical rehabilitation of the imperial past, apparently, is not a purely Russian trend. For example, several years ago, while studying the peculiarities of the historical consciousness of Turkish students, I noticed their positive reassessment of the historical role of the last sovereign Turkish Sultan Abdūlhamid II: regarded for a long time as a reactionary and a tyrant, he is now becoming an example of a "good ruler," who did much to modernize his country. (It is difficult to get rid of the impression that this trend in the evolution of the historical consciousness has become one of the cultural and psychological pillars or at least a correlate of the current Erdoganian neo-Ottomanism.)

Note that the share of those who were undecided or who answered that none of the periods of Russian history corresponded to their ideal was very large, over $43 \%$. We regularly obtained similar results in the past. This suggests that historical consensus in modern Russian society is relative, by no means stable, and may undergo certain changes in the future. This, in all likelihood, can have specific political consequences, opening, among other things, the prospect of some reformatting of the supreme institutions of state power. 
Table 1. In what historical epochs would Russians prefer to live, $\%$ of the number of respondents

\begin{tabular}{|c|c|c|c|c|c|c|c|c|}
\hline 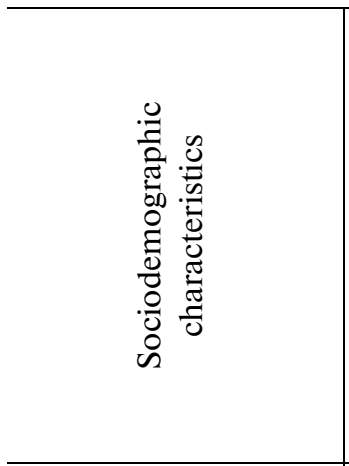 & 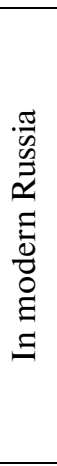 & 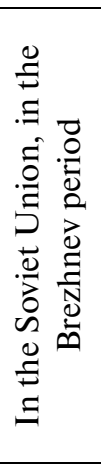 & 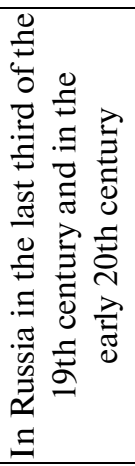 & 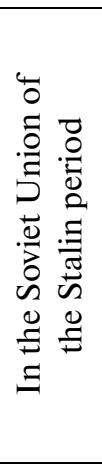 & 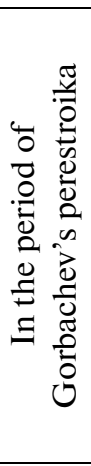 & 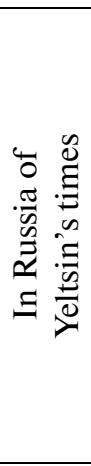 & 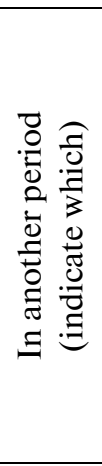 & $\begin{array}{l}\frac{D}{0} \\
\frac{0}{0} \\
\frac{0}{0} \\
\frac{0}{0}\end{array}$ \\
\hline Total & 34 & 25 & 4 & 3 & 1 & 1 & 1 & 31 \\
\hline \multicolumn{9}{|c|}{ Age } \\
\hline $18-30$ years of age & 41 & 8 & 5 & 5 & 1 & 1 & 3 & 37 \\
\hline $31-40$ years old & 44 & 15 & 4 & 2 & 1 & - & 1 & 32 \\
\hline $41-50$ years old & 34 & 23 & 4 & 4 & - & - & 1 & 33 \\
\hline $51-60$ years old & 22 & 41 & 3 & 3 & 1 & - & 1 & 30 \\
\hline 60 and older & 25 & 42 & 3 & 2 & - & 1 & 2 & 24 \\
\hline \multicolumn{9}{|c|}{ Education } \\
\hline Incomplete secondary & 34 & 28 & 2 & 3 & 2 & 2 & 2 & 28 \\
\hline General secondary & 29 & 30 & 3 & 4 & 1 & 1 & 2 & 30 \\
\hline Secondary vocational & 34 & 26 & 3 & 3 & 1 & - & 1 & 33 \\
\hline $\begin{array}{l}\text { Higher, including } \\
\text { undergraduate }\end{array}$ & 37 & 21 & 6 & 3 & 1 & - & 2 & 29 \\
\hline \multicolumn{9}{|c|}{ Internet use } \\
\hline Every day & 37 & 20 & 5 & 3 & 1 & - & 2 & 32 \\
\hline Several times a week & 31 & 28 & 3 & 1 & 1 & - & 1 & 33 \\
\hline Several times a month & 29 & 31 & 2 & 4 & - & 2 & - & 31 \\
\hline Several times a year & 33 & 33 & - & - & - & - & & 33 \\
\hline Never & 23 & 44 & 2 & 4 & - & 1 & 2 & 23 \\
\hline \multicolumn{9}{|c|}{ Financial situation } \\
\hline Very good, rather good & 47 & 13 & 5 & 2 & 2 & - & 2 & 29 \\
\hline Satisfactory & 36 & 24 & 3 & 3 & 1 & - & 2 & 31 \\
\hline Rather bad, bad & 23 & 33 & 4 & 4 & - & 1 & 1 & 34 \\
\hline Undecided & 39 & 25 & 5 & - & 2 & - & 2 & 28 \\
\hline
\end{tabular}

Let us see what will change if we formulate practically the same question a little differently: "If it depended on you, in what era of Russian history would you like to live?" In this case, we are no longer talking about an ideal but about a "good society" [7] or, at least, an acceptable society. As it turned out, the share of the two most popular periods in this case increases-in the first case by $6 \%$ and in the second by
$12 \%$, while the share of the rest decreases, so that the attractiveness of the "Brezhnev era," on the one hand, and the "Putin era," on the other, appears even more prominently. True, the share of representatives of older age cohorts (aged 50+) who would prefer to return to the days of "developed socialism" exceeds $40 \%$, while among those who practically did not even see the 1970s, $40 \%$ do not feel the need to experiment 
with the "time machine" and would not trade the current era for any other. To summarize, both Soviet reality and Putin's Russia are, of course, not heaven on Earth, but nothing better has yet been invented for us (Table 1).

\section{HISTORICAL TRUTH AS A VALUE REFERENCE}

Attempts to convince us of the need to revise and re-evaluate Russian history on the basis of its versions that are being developed and promoted now in the West, to put it mildly, encounter neither understanding nor sympathy in Russian society. Judging by the data of our study, more than half of the country's population is convinced that our common future depends on the interpretation of the past, and, therefore, the struggle for the past is of great political importance, including international.

Russians insist on counteracting the distortion of historical truth, especially when it comes to the Great Patriotic War. Over $37 \%$ of respondents declared themselves to be supporters of decisive disputes with those who substitute historical facts, and $34 \%$ consider it necessary to popularize our understanding of history in films and literature, as well as in the media and social networks. In total, this is over $70 \%$ of the respondents. About $8 \%$ of Russians prefer to ignore our ill-wishers (probably, according to the principle "dogs bark, but the caravan moves on"), and about the same number rely on scientific objectivity and hope to bring together different versions of historical memory through the discussion of controversial issues by scientists. Only one out of twenty-five survey participants replied that one should unconditionally accept criticism of our country and rethink accordingly some events in our history. Yet if we focus on the fairness of criticism, then such a position does not necessarily contradict the opinion of the majority: it can only mean differences in attitude to the opinion of opponents and their arguments. After all, one thing is precisely verified facts and real actions of certain historical figures, and quite another thing is assumptions about intentions, conjectures, and arbitrary reconstructions, such as the statements that in the summer of 1941 the Red Army suffered defeats because Stalin had planned to attack Germany and had been preparing for offensive actions, and therefore had not prepared the troops for defense.

In this connection, of course, the question of intellectual responsibility immediately arises. Do we defend the version of history accepted in Russia simply because it is "ours," satisfies our pride, and legitimizes the political course of the Russian state? Or is it more important here that it correspond to the real situation?

In the course of our study, an attempt was made to get an answer to these questions. The respondents were offered a choice between two alternatives: "to give a complete and honest picture of history, mentioning not only bright and heroic moments but also its dark, unsightly side" or "not to stir up tragic pages of history, as it splits the society and prevents its consolidation." In other words, do we need a complex and multifaceted historical truth or only heroic myths? Frankly, there are quite a few supporters of the second option in Russian society, a little less than $30 \%$. Still, the share of those who prefer historical truth, no matter how bitter it may be, turned out to be approximately two times higher. Note that the picture for all the main sociodemographic groups (by age, education, social status) turns out to be quite even: the values of the corresponding indicators deviate from the average for the sample by no more than 5\%. Therefore, there is no reason to say that Russian society is prone to self-blinding and narcissism; at the same time, however, it prefers to refrain from self-flagellation.

In large measure, Russians understand that historical knowledge has a certain specificity and cannot provide us with eternal truths. About $39 \%$ of our respondents agreed that assessments of historical figures and events can change over time. However, over $48 \%$ emphasized something else as well-the need to develop a unified view, at least regarding the main historical events. Thus, the need for stable reference points, for a universally accepted picture of the world and a large-scale historical narrative inscribed in this picture is felt very strongly in Russian society.

\section{FUNDING}

This article was supported by the Russian Science Foundation, grant no. 20-18-00505.

\section{REFERENCES}

1. Woodrow Wilson National Fellowship Foundation. https://woodrow.org/americanhistory/. Cited October 2, 2020.

2. Losing America's Memory. American Council of Trustees and Alumni, 2000. https://www.goacta.org/news-item/losing_americas_memory/. Cited October 4, 2020.

3. Woodrow Wilson Foundation American History Initiative. 50-state Survey Data (2019). https://woodrow.org/wp-content/uploads/2019/04/WW-AHI-50State-Data-Pamphlet-3-20-19.pdf. Cited October 4, 2020.

4. https://wciom.ru/index.php?id=23\&page $=4$. Cited October 22, 2020.

5. I. M. Savel'eva and A. V. Poletaev, Social Beliefs about the Past, or whether Americans Know History (Nov. Lit. Obozr., Moscow, 2008) [in Russian].

6. A. L. Andreev, "Student and history," Vyssh. Obr. Ross., No. 7, 38-44 (2016).

7. V. G. Fedotova, Good Society (Progress-Traditsiya, Moscow, 2005) [in Russian].

Translated by B. Alekseev 